\title{
The Whole is Greater than the Sum of its Parts - Synergies between Non- Digital and Digital Business Models within Companies
}

\author{
Jonas Toutaoui \\ Darmstadt University of Technology - TU Darmstadt \\ toutaoui@ise.tu-darmstadt.de
}

\begin{abstract}
Digital transformation is increasingly becoming a major concern for established companies. Part of the digital transformation is often the creation of new business models based on digital technologies, which do not replace the established business model but act as additional source of revenue. Two concurrent business models within one company creates the opportunity of synergies between these business models. However, knowledge on interactions between two business models, specifically digital and nondigital, remains in an embryonic stage. This multicase study, based on companies from various industries and size, addresses this shortcoming. Following the business model canvas and the theories of resource relatedness and complementarity, we show how both business models can propel each other thanks to value and cost synergies between them. Finally, we offer rich insights for practitioners on what type of synergies they can benefit from and present guidelines they can use to identify and unlock these synergies.
\end{abstract}

\section{Introduction}

At a time of digital disruption throughout the global economy, many established companies face digitalization challenges and develop diverse digital transformation strategies as responses [1, 2]. These digital transformations often have in common the development of new business models (BMs), based on emerging technologies. Such additional, new digital BMs do not replace the established non-digital BMs but act as additional source to create economic value. For instance, the automotive company Daimler AG built car2go, a digital car-sharing BM for which all interactions with the customers happen through a smartphone application [3]. This new digital BM does not herald the end of the established BM of Daimler AG (development, manufacturing, and sales of vehicles). Rather Daimler AG, like many other pre-digital companies, now has two concurrent BMs,

\author{
Alexander Benlian \\ Darmstadt University of Technology - TU Darmstadt \\ benlian@ise.tu-darmstadt.de
}

one being non-digital and one being digital. Furthermore, several companies have not yet started their digital transformation, meaning that even more concurrence between digital and non-digital BMs is expected for the near future [4].

Related research in the past focused mainly on BM definitions and frameworks or studied single BMs [5]. Few studies shed little light on the synergies and conflicts between a BM based on premium products and a BM based on low-cost products for the same market and within the same company [e.g., 6]. However, the possibilities of differentiation between digital and non-digital BMs are far greater and this realm of synergies remains largely unexplored [7]. Synergies, defined as "the combined power of a group of things when they are working together that is greater than the total power achieved by each working separately" [8], mark an important topic for research and practice for decades [e.g., 9]. The emergence of digital technologies and business models now fuels the search for novel synergies.

Thus, we pose the following research question:

What synergies exist between a new additional digital business model and the established nondigital business model within the same company?

We conducted a qualitative, interpretive multicase study to answer this research question. Each case company had built up a new additional digital $\mathrm{BM}$ in the past, thus enabling a retrospective data collection. To collect and analyze the data we employed the prevalent business model canvas and the theories of complementarity and resource relatedness [10-13]. We interviewed 16 managers and C-level executives from eight different case companies of various industries and size. In addition, we examined archival public and internal secondary data of the case companies.

We reveal synergies in each case, with many synergy types repeating across cases. While the new digital BMs primarily thrive thanks to cost synergies via shared customer relationships and channels with the established BMs, the same established BMs 
benefit from value synergies through increased capabilities and strengthened value propositions.

Our study contributes to the IS research stream on digital BMs, following the call of Veit et al. [14], by offering new insights on the synergies between multiple BMs within a company in the context of digital transformation. We also present theoretical contributions to the concept of synergy, the theory of relatedness, and the theory of complementarity by defining synergies on a BM level.

Finally, we derive practical insights for managers and executives responsible for new digital BMs or established BMs. We offer an overview of synergies they might unlock to spur the development of their own BMs. Our practical guidelines also give impulses on how to identify and unravel BM synergies in the digital transformation.

\section{Conceptual background}

\subsection{Digital transformation leads to new digital BMs in established companies}

Across all sectors, established companies currently face a wave of digitalization, the adoption and use of emergent digital technologies in an individual, organizational, and societal context [15]. As a reaction to this wave, pre-digital companies start digital transformations which Vial [16] describes as "a process that aims to improve an entity by triggering significant changes to its properties through combinations of information, computing, communication, and connectivity technologies". The importance of this topic is also reflected by the increasing number of publications in premier IS journals [16]. One aspect of the digital transformation is in many cases the development of new BMs through the combination of the evoked technologies. Indeed, pre-digital companies regard these digital technologies as potential revenue sources [17].

The build-up of new organizational units, such as digital innovation units or internal start-ups, goes hand in hand with new additional digital BMs and digital transformation as these emerging units often take the responsibility for the development (and operation) of the additional BM [18]. Thus, the new $\mathrm{BM}$ is frequently physically separated from the established BM [19].

\subsection{Business models and the difference between digital and non-digital BMs}

Business models are an important topic for practitioners and researchers alike since the mid- 1990s, also exposed by the important number of publications in practitioner-related journals [20]. While many definitions and frameworks exist for BMs [5], we adopt the widespread definition and business model canvas framework from Osterwalder and Pigneur [10] to guide our research. Hence, we define a BM as "the rationale of how an organization creates, delivers, and captures value" [10].

The business model canvas is not tailored to a specific context or industry (e.g., e-commerce) like other BM frameworks. Hence, it suits our research endeavor very well. Figure 1 below depicts the business model canvas that will be used later in this paper and in table 1 we describe each of the nine business model components.

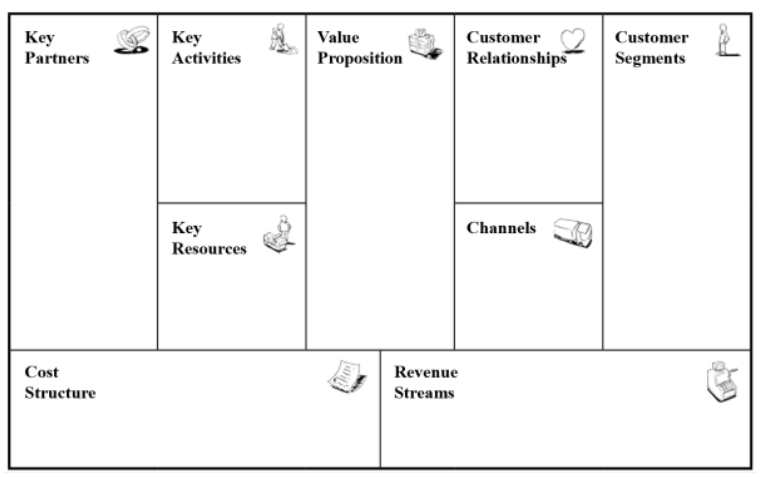

Figure 1. The business model canvas [10]

Table 1. Description of the business model components [10]

\begin{tabular}{|ll|}
$\begin{array}{l}\text { Business } \\
\text { model } \\
\text { component }\end{array}$ & Description \\
\hline Key Partners & $\begin{array}{l}\text { The network of suppliers and } \\
\text { partners that make the business } \\
\text { model work. }\end{array}$ \\
\hline $\begin{array}{l}\text { Key } \\
\text { Activities }\end{array}$ & $\begin{array}{l}\text { The most important activities a } \\
\text { company must do to make its } \\
\text { business model work (e.g., } \\
\text { supply chain management). }\end{array}$ \\
\hline $\begin{array}{l}\text { Key } \\
\text { Resources }\end{array}$ & $\begin{array}{l}\text { The most important assets } \\
\text { required to make a business } \\
\text { model work. }\end{array}$ \\
\hline $\begin{array}{l}\text { Cost } \\
\text { Structure }\end{array}$ & $\begin{array}{l}\text { The most important costs } \\
\text { incurred while operating under a } \\
\text { particular business model. }\end{array}$ \\
\hline $\begin{array}{l}\text { Value } \\
\text { Proposition }\end{array}$ & $\begin{array}{l}\text { The bundle of products and } \\
\text { services that create value for a } \\
\text { specific customer segment. }\end{array}$ \\
\hline
\end{tabular}




\begin{tabular}{|ll|}
\hline $\begin{array}{l}\text { Customer } \\
\text { Relationships }\end{array}$ & $\begin{array}{l}\text { Types of relationships a } \\
\text { company establishes with } \\
\text { specific customer segments. }\end{array}$ \\
\hline Channels & $\begin{array}{l}\text { Channels describe how a } \\
\text { company communicates with } \\
\text { and reaches its customer } \\
\text { segments to deliver a value } \\
\text { proposition. }\end{array}$ \\
\hline $\begin{array}{l}\text { Customer } \\
\text { Segments }\end{array}$ & $\begin{array}{l}\text { Different groups of people or } \\
\text { organizations a company aims to } \\
\text { reach and serve. }\end{array}$ \\
\hline $\begin{array}{l}\text { Revenue } \\
\text { Streams }\end{array}$ & $\begin{array}{l}\text { Represents the cash a company } \\
\text { generates from each customer } \\
\text { segment. }\end{array}$ \\
\hline
\end{tabular}

To answer our research question, it is necessary to differentiate between digital and non-digital business models. According to Veit et al. [14] a BM is digital "if changes in digital technologies trigger fundamental changes in the way business is carried out and revenues are generated" [21]. Furthermore, digital business models are characterized by an increased complexity, mutability, and pace due to the increased number of key partners compared to nondigital business models. Simultaneously, digital business models benefit from an improved costrevenues-ratio thanks to better flow of information (resulting in lower communication and transaction costs) and thanks to practically zero marginal cost when reproducing digital products or services [22].

\subsection{Concurrent business models and the two types of synergy}

In the past decades, many established companies had built up additional business models as an instrument for strategic positioning in one market [23]. These concurrent BMs enabled companies to offer a low-price version and a premium version of a product within the same market. Examples of companies which adopted such concurrent BMs are Toyota with its premium brand Lexus, SMH with its lower-price Swatch brand, or Nestlé with its Nespresso subsidiary offering premium coffee [19]. These concurrent business models notably differed in their cost structure [23]. Researchers, especially in management and strategy disciplines, studied integration mechanisms between such BMs and tensions that arise within the company [e.g., 6, 19]. Afterwards, Wiener et al. [24] and Hoßbach [25] laid ground for further IS research by identifying synergies and tensions in omni-channel businesses (e.g., newspaper industry).
While these studies provide valuable insights for research and practice, digital BMs tend to be more differentiated to established BMs than only in their cost structures or channels, hence offer additional synergy potential [26].

To identify and analyze potential synergies we adopt the theory of resource relatedness and the theory of complementarity. Originally developed in the strategy and economics research, they explain most of the synergy concept and have also been applied in IS research many times [12, 27, 28]. The theory of resource relatedness states that the use of common resources across units creates so-called subadditive cost synergies, meaning that the units benefit from reduced joint costs [13]. Similarly, the economic theory of complementarity affirms that distinct resources can be interdependent. A set of resources is then complementary, when the returns to a resource vary depending on the levels of other resources or as Milgrom [11] originally declares: "Doing more of one thing increases the returns to do more of another" [11]. Complementary resources create super-additive value synergy as their joint value is greater than the sum of their individual values [27].

Similar to Radszuwill and Fridgen [28] we adapt the definitions of the two types of synergies (superadditive value synergy and sub-additive cost synergy) to our BM context with (A) and (B) being two BMs:

- Two BMs benefit from super-additive BM value synergy if the value created, delivered or captured is higher compared to conducting the $\mathrm{BMs} \quad$ individually: Value(A+B)>Value(A)+Value(B).

- Two BMs benefit from sub-additive BM cost synergy if the costs incurred when developing or operating the BMs is lower compared to the costs of development or operations of the BMs individually, thanks to sharing of $B M$ components: $\operatorname{Costs}(\mathrm{A}+\mathrm{B})<\operatorname{Costs}(\mathrm{A})+\operatorname{Costs}(\mathrm{B})$.

\section{Research methodology}

We follow the established research practice and philosophy of social constructivism and opt for an interpretive multi-case study approach. Knowledge on the interaction, namely synergies, between concurrent digital and established BMs is scarce and an interpretive approach is especially suited to generate findings for new areas of research [29]. Moreover, we aim to study concurrent BMs within companies, which is challenging to simulate in an experimental setting. Our approach covering multiple cases allows us to study synergy potentials for 
different industries and size and for different established and additional digital business models to find patterns across cases [29]. In the design and conduct of our research we adhere to the principles of Klein and Myers [30].

\subsection{Data collection}

To restrain companies as potential cases we applied several criteria: (1) The company had to be a well-established in its market to demonstrate the seriousness of the established non-digital BM. This criterion excluded "pure-play" digital companies (e.g., Amazon). (2) The new digital BM had to show an important level of maturity which we defined by success with first customers, to sufficiently inform the research. Furthermore, companies were selected from various industries and size to increase validity and reliability.

Interview partners were selected based on the key informant method and we focused on senior managers of which we assumed being knowledgeable about both concurrent BMs in their company (based on their position and experience in the company) [31]. In each case, we employed our interview guideline and did two semi-structured interviews to counter biases of the interview partners and [32, 33].

For each case, we obtained internal documentation or public information as additional data, to triangulate our findings and further increase their validity.

Once 16 interviews out of eight cases were concluded, we recognized that we had reached theoretical saturation as the coded transcripts of the last case had revealed no new findings. Following Beattie et al. [34] we terminated our collection of case companies, resulting in eight cases which fits to Eisenhardt's [35] recommendation of four to ten cases for qualitative IS research. Table 2 below summarizes our cases.

Table 2. Case companies and interview

\begin{tabular}{|c|c|c|c|c|}
\hline ID & Industry & $\begin{array}{l}\text { Reve- } \\
\text { nue (bn } \\
\text { EUR) }\end{array}$ & $\begin{array}{l}\text { Em- } \\
\text { ployees }\end{array}$ & $\begin{array}{l}\text { Interview } \\
\text { partners }\end{array}$ \\
\hline \multirow[t]{2}{*}{1} & \multirow[t]{2}{*}{ High-tech } & \multirow[t]{2}{*}{$\sim 6$} & \multirow[t]{2}{*}{$\begin{array}{l}10,000- \\
50,000\end{array}$} & $\begin{array}{l}\text { Head of digital } \\
\text { innovation unit }\end{array}$ \\
\hline & & & & $\begin{array}{l}\text { Project manager } \\
\text { within IT }\end{array}$ \\
\hline \multirow[t]{2}{*}{2} & \multirow[t]{2}{*}{$\begin{array}{l}\text { Pharma- } \\
\text { ceutical }\end{array}$} & \multirow[t]{2}{*}{$\begin{array}{l}\sim 20 \\
\end{array}$} & \multirow[t]{2}{*}{$>50,000$} & $\begin{array}{l}\text { Management team } \\
\text { member of digital } \\
\text { innovation unit }\end{array}$ \\
\hline & & & & $\begin{array}{l}\text { Team leader } \\
\text { within IT }\end{array}$ \\
\hline
\end{tabular}

\begin{tabular}{|c|c|c|c|c|}
\hline \multirow[t]{2}{*}{3} & \multirow[t]{2}{*}{ Retail } & \multirow[t]{2}{*}{$\sim 6$} & \multirow[t]{2}{*}{$<10,000$} & $\begin{array}{l}\text { Chief Customer } \\
\text { Officer }\end{array}$ \\
\hline & & & & $\begin{array}{l}\text { Chief Information } \\
\text { Officer }\end{array}$ \\
\hline \multirow[t]{2}{*}{4} & \multirow[t]{2}{*}{ Mobility } & \multirow[t]{2}{*}{$\sim 0.8$} & \multirow[t]{2}{*}{$<10,000$} & $\begin{array}{l}\text { Chief Digital } \\
\text { Officer }\end{array}$ \\
\hline & & & & $\begin{array}{l}\text { Chief Information } \\
\text { Officer }\end{array}$ \\
\hline \multirow[t]{2}{*}{5} & \multirow[t]{2}{*}{$\begin{array}{l}\text { Auto- } \\
\text { motive }\end{array}$} & \multirow[t]{2}{*}{$>100$} & \multirow[t]{2}{*}{$\begin{array}{l}> \\
100,000\end{array}$} & $\begin{array}{l}\text { Management team } \\
\text { member of digital } \\
\text { innovation unit }\end{array}$ \\
\hline & & & & $\begin{array}{l}\text { Team leader } \\
\text { within IT }\end{array}$ \\
\hline \multirow[t]{2}{*}{6} & \multirow[t]{2}{*}{ Utilities } & \multirow[t]{2}{*}{$\sim 20$} & \multirow[t]{2}{*}{$\begin{array}{l}10,000- \\
50,000\end{array}$} & $\begin{array}{l}\text { Management team } \\
\text { member of digital } \\
\text { innovation unit }\end{array}$ \\
\hline & & & & $\begin{array}{l}\text { Team leader } \\
\text { within IT }\end{array}$ \\
\hline \multirow[t]{2}{*}{7} & \multirow[t]{2}{*}{ Logistics } & \multirow[t]{2}{*}{$\sim 1.5$} & \multirow[t]{2}{*}{$<10,000$} & $\begin{array}{l}\text { Management team } \\
\text { member of digital } \\
\text { innovation unit }\end{array}$ \\
\hline & & & & $\begin{array}{l}\text { Chief Information } \\
\text { Officer }\end{array}$ \\
\hline \multirow[t]{2}{*}{8} & \multirow[t]{2}{*}{$\begin{array}{l}\text { Auto- } \\
\text { motive }\end{array}$} & \multirow[t]{2}{*}{$\sim 15$} & \multirow[t]{2}{*}{$>50,000$} & $\begin{array}{l}\text { Head of digital } \\
\text { innovation unit }\end{array}$ \\
\hline & & & & $\begin{array}{l}\text { Team leader } \\
\text { within IT }\end{array}$ \\
\hline
\end{tabular}

\subsection{Data analysis}

We followed established recommendations for our qualitative data analysis and proceeded in two steps [36]. Firstly, a within-case analysis led to the craft of two business model canvases per case, one for the established BM and one for the new digital BM. Secondary data was also helpful in creating these canvases. In detail, we employed a selective coding technique, identifying transcript sections that mapped to one of the nine business model components (which therefore acted as seed codes). These business model canvases served as unit of analysis further on. Secondly, we identified synergies based on within-case and across-case analyses. Using open and axial coding techniques we identified parts of the qualitative data referring to one of the two synergy types and coupled these synergies to the respective BM components (e.g., "We presented the prototype of our digital BM to customers to get feedback: our colleagues presented the newest instruments in the front, we were at the same booth in the back" to code "cost synergy in sales and marketing / channels").

Coding was done by several researchers who showed a high level of agreement for randomly selected sets of qualitative data. 


\section{Results}

Our study reveals three key findings and guidelines for practitioners. Firstly, digital platforms play a crucial role among the types of additional digital BMs established companies build up, tapping into the same or completely new customer segments. Secondly, established BMs can vastly benefit from an additional digital BM as it allows to extend their established value proposition, connecting existing physical products to a new digital platform. It also allows to raise new key resources in terms of capabilities. Thirdly, growth of new digital BMs is accelerated by the sharing of industry knowledge, channels, and customer relationship resources. Regarding guidelines, we emphasize the importance of acceptance of the additional digital BM via enforced internal communication, formal and informal alignment, and the re-use of what exists instead of re-inventing the wheel.

\subsection{Finding 1: The prevalence of digital platforms as additional digital business models}

The cases reveal that established companies focus on digital platforms as new digital BMs. Case 6, a large utility company, is the only company in our sample that does not develop a digital platform (so far) but develops new Software-as-a-Service products for business customers (e.g., smart energy and facility management solutions) besides its established $\mathrm{BM}$ of producing and selling energy to private and business customers. All other new digital BMs, for business-to-business (B2B) and business-toconsumer (B2C) companies alike, rely on platform BMs based on cloud technology. Platform BMs are notably characterized by providing a set of stable (software) product elements that supports variety and evolvability by constraining the linkages among the product elements delivered by complementors [37, 38].

The main difference between the digital platform BMs of the case companies in our sample is whether the companies target new or existing customer segments.

A regional retailer for example (case 3) built an online platform for the existing customer segment to shop everywhere and at any time, integrating its fashion stores for click-and-collect functions and to allow personal shoppers in the stores to order online in case of articles being sold out in store (to be delivered to the store or directly to the customer). On its digital platform, the retailer also adds fashion bloggers and influencers which directly exchange with online shoppers. Similarly, a global company from a different industry, namely an automotive original equipment manufacturer (OEM), set up a digital platform mainly to serve their existing customers with new services (case 8). Apart from the established BM of developing, manufacturing and selling cars, the digital platform BM allows the same customers to connect with parking garages to use digital payment methods for parking fees and avoid paper-based parking tickets.

While the previous examples from B2C companies across various industries show that digital platform BMs allow to serve the same customer segments, some B2B companies employ a new digital BM to target new customer segments. Case company 7 construes such a case. The global service provider for logistics companies (e.g., freight forwarders) extends its customer segments with its digital platform. This new digital BM relies on connecting the freight sender and receiver and offer them real-time positioning information thanks to a device being attached to the freight, leaving out the freight forwarders.

Summarizing, we observe B2C companies focusing their digital (platform) BMs on existing customer segments and some B2B companies adopting digital platforms to open their business to new customer segments. Nonetheless, no case was observed in which a B2B or B2C company switched its focus and built a digital BM purely for private or business customers respectively.

\subsection{Finding 2: Established business models mostly benefit from increased value}

In different cases we discovered value synergies between the concurrent BMs. Synergies between additional digital BM and established BM allow an innovation of the established BM, especially regarding its value proposition and key resources.

Existing mechanical products (e.g., medical technology in case 1), which are at the core of the established non-digital BM, are now directly integrated to the digital platform BM, thereby offering new features. As this integration is done per default within existing production processes, efforts are limited. Hence, the digital BM significantly increases the value proposition of the established BM without important additional efforts. In that sense, the established BM acts as complementor to the digital platform BM and we observe a platform ecosystem within a company. In case 1 , a global manufacturer of instruments for medical imagery decided to build a 
new digital BM based only on cloud technology with no physical product. The pay-per-use platform that was built offers different image processing techniques, optimized for the medical context (e.g., count of cells, marking of specific cells). The platform is independent of the instrument with which the image was taken and allows the integration of instruments of many manufacturers and of image processing applications of other parties. Instruments of the case company are now shipped with the integration to the digital platform by default: with one additional button on the instruments, images are directly sent to the platform. Thus, customers now experience a seamless imagery process in laboratories or hospitals. This new generation of instruments but also existing instruments now offer additional value to the customers by offering image processing techniques without an important cost increase for the established BM. The digital platform $\mathrm{BM}$ also benefits as a complementor, the own company, is included from the very first day of the platform.

Another example of a value synergy marks case 8. The global automotive OEM started a digital fleet management platform, connecting various freight forwarders with OEMs to offer them real-time positioning information about the vehicles and predictive maintenance services. The platform is also open to vehicles of other OEMs but requires freight forwarders to install a tracker device on their vehicles. Within the established BM (development, manufacturing, and sales of vehicles) new produced vehicles are now equipped and sold by default with the tracker device. Thus, these vehicles offer the additional platform features (without great effort from neither the established BM nor the customers) and show an increased value proposition:

"Equipping our vehicles with our device is a first important step closer to our vision of a fully networked transport and logistics value chain. At the same time, it is a prerequisite for giving our customers access to digital value-added services." - CEO case 8 (publicly available interview)

New digital BMs may not only increase the value proposition of the established BM but also increase the value of its key resources: the co-workers' capabilities. In all examined cases the development of new digital BMs was based on agile, cloud-based, software development methods - methods that were prior unknown to the case companies according to the interview partners. Through knowledge exchange on these new methods, co-workers focusing on the established BM were trained on new competencies and especially, as managers and $\mathrm{C}$-level executives explained, became more customer centric as these new methods usually insist on regular customer interaction (e.g., regular customer feedback):

"We did training days, did agile coaching etc. In each project we involve people [working within the established BM] which work with us and by our methods" - Head of digital innovation unit (case 1)

Therefore, the capabilities and value of the coworkers driving the established BM increase, without important costs for the BM.

Finally, some interview partners report that with the presence of a successful new digital BM, the coworkers (as key resource for both business models) experience a higher level of satisfaction and identification with the employer. One manager describes it as follows:

"Sales, for example, likes to talk about us [the digital BM]. Co-workers are proud, and you hear things like: Awesome, CaseCompany as a family business knows how to use digitalization for itself." - Management team member of digital innovation unit (case 7)

\subsection{Finding 3: Cost synergies accelerate the success of new digital business models}

"Why is CaseCompany a really good owner for this digital platform? That's because we have an amazing distribution network where we have a good relationship with 50 percent of all targeted doctors" - Management team member of digital innovation unit (case 2)

Across all cases, the most important synergy we observed between digital and established BM concerns channels and customer relationships.

Even though the digital BM is based on a digital product or platform radically different than previous physical products of the case companies, existing customer relationships and established channels were used to spur the success (in terms of sales) of the digital BM. Especially for digital platform BMs, where a critical user mass is necessary to overcome the chicken-and-egg-problem [39], this acceleration is deemed crucial by interview partners to quickly reach an important number of users as the quote above shows. In detail, the existing sales force is used to promote the new digital BM based on its relationship with known customers of the established BM. Other channels were also activated for the new digital BM such as industry fairs where the digital BM was promoted to customers which originally might have visited the company's booth for the established BM. Replicating these customer relationships (i.e., building up a new sales team) 
would have been very expensive and time-consuming for the digital BM, which hence experienced important cost synergies thanks to the established BM. This synergy is still existent if the digital BM targets new customer segments. Indeed, several interview partners declare that the new digital BM builds upon the strong brand of the established BM to gain credibility and convince customers much faster than creating and building a brand reputation on its own:

"If you try to get an appointment with an OEM plant manager, you will have a hard time as a start-up. But when you call and say "we are from CaseCompany", you get an appointment. That's pretty valuable." - Management team member of digital innovation unit (case 7)

Furthermore, several interview partners express that the development of the digital BM takes less erroneous paths (and was therefore faster and less expensive) as a key resource of the established BM is used: the large body of industry experience. Although knowledge on digital topics may be scarce within the case company, knowledge on the specific industry's customers is broad which allows to quickly identify customer pain points. The following quote succinctly points it out:

"We build [our digital BM] on our competence in medical technology. We know our customers." - Head of digital innovation unit (case 1)

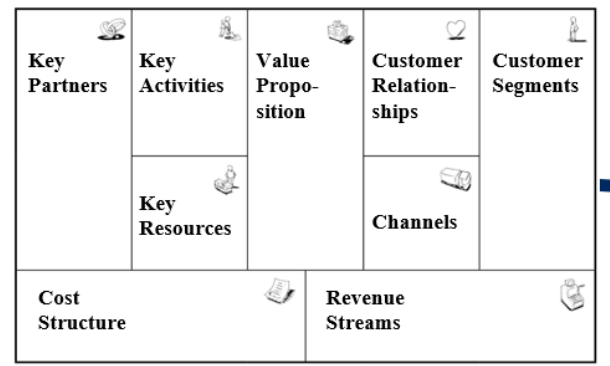

\section{Concurrent established (non-digital)} and digital $\mathrm{BM}$ in isolation

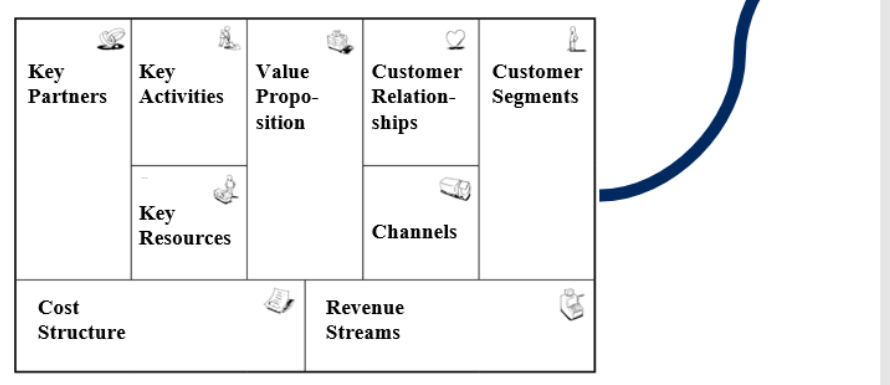

In total, digital BMs benefit from key resources, channels, and existing customer relationships of the established $\mathrm{BMs}$, leading to reduced marketing and sales costs and a reduced cost structure overall. Surprisingly, no cost synergies in terms of IT costs are found. Our interview partners affirm that they had built up a new bi-modal IT architecture to conform to the requirements of the digital $\mathrm{BM}$, leaving no room for IT cost synergies.

The figure 2 below summarizes the previous two findings.

\subsection{Practical guidelines to identify and unlock business model synergies}

Once an additional digital BM is crafted, practitioners can follow the requirements below to power the success of the digital BM and innovate their established BM:

1. First, create acceptance of the additional digital $\mathrm{BM}$ within your company. A new BM might create a detrimental feeling of competition among co-workers focusing on the concurrent BMs and related conflicts might surface soon. A company's top-management must quickly resolve such conflicts by clarifying the role each $\mathrm{BM}$ is playing for the future of the company and

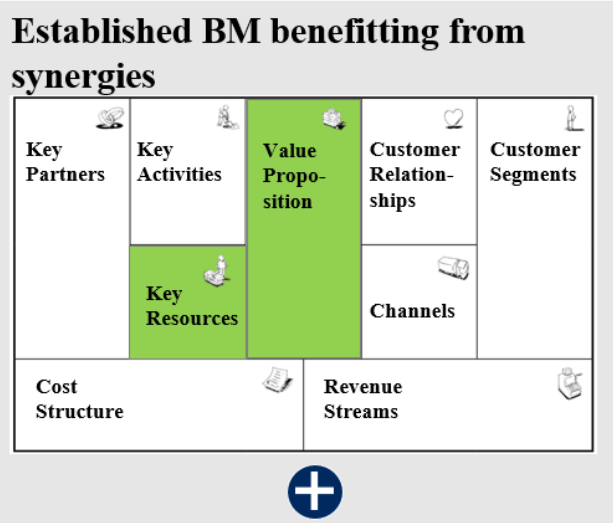

Digital BM benefitting from synergies

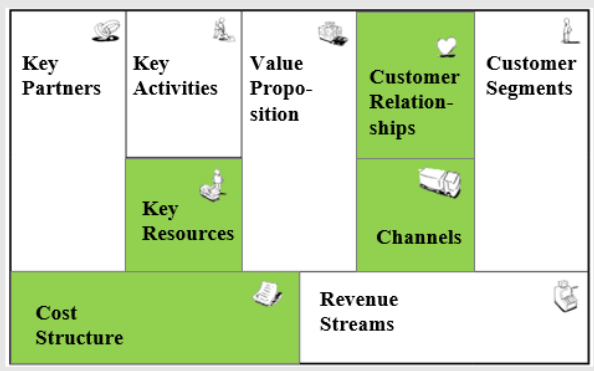

BM components for which synergy potential exists

Figure 2. Synergies between established and digital BMs (research findings 4.2 and 4.3) 
by clearly communicating that a new BM does not herald the end of the established BM but rather builds on and extends the established BM. On a lower hierarchy, internal communication can also be enforced. Especially communication about the methods used for the new BM and its progress (e.g., first revenue captured) can spur the interest of other coworkers and prove the seriousness of the digital BM.

2. Second, establish continuous knowledge exchange between BMs. Potential for synergies will only be identified by co-workers if they truly understand both BMs. Both BMs are usually developed and operated in different organizational units that even are in physically different locations. Therefore, create informal alignment and knowledge exchange opportunities like round tables, common workshops or mutual workplace visits. Also, add formal alignment and knowledge exchange elements like job rotations between both BMs or "liaison officers": people from one BM working within the team of the concurrent BM, dedicated to gather and transfer knowledge.

3. Third, don't reinvent the wheel. Your digital BM might be on a growth path and cost reductions not in focus. Simultaneously, an increase of the value proposition of your established BM might not have an important priority. However, concurrent BMs enable both without important efforts. Analyze what resources of the established BM can be re-used rather than built up from the ground up for the new digital BM. Simultaneously, evaluate how to link your concurrent BMs to each other as complementary offer to your customers instead of developing completely new features for both BMs independently.

\section{Discussion}

Many pre-digital companies that have embarked on a digital transformation now operate two concurrent BMs, one established non-digital and one additional being a digital BM. This study uncovers synergies between BMs in such companies and reveals that both BMs can benefit from each other. Consistent with the perspective that digital business models construe a topic inherent to IS research, we offer insights into the area of interactions between digital and non-digital BMs which is in an embryonic stage but gains importance with digital transformation. We extend previous research which focused on interactions between premium vs. low- cost or online vs. offline BMs, and demonstrate that even radically different BMs, that may even target different customer segments, allow for synergies. Thereby, we also present how growth of digital BMs within established companies can be spurred, namely by using the brand, channels, customer relationships, and key resources (e.g., industry knowledge) from the established BMs. Moreover, we add a new perspective on BM innovation by revealing how established BMs are innovated by connecting them to a digital platform BM, forming a platform ecosystem within the same company. In regard to the theories of complementarity and resource relatedness, we take a novel perspective and define the concepts of subadditive cost synergy and super-additive value synergy on a BM level.

In addition to our theoretical contributions, our study offers important insights and guidance for practitioners managing concurrent BMs. First, we show managers of established or additional digital BMs on what BM components they have to pay attention to further increase their value proposition or avoid costs. Managers may also want to use our practical guidelines as a blueprint to design and implement interventions to continuously identify and unlock synergies.

Despite these contributions, this study is not without some limitations. First and foremost, we acknowledge that the sample of cases is limited in size. Additionally, even if we reached a theoretical saturation, all case companies are multi-nationals headquartered in Germany. Companies from other regions with different culture might approach the digital transformation, digital BMs, and synergies differently. Finally, we based our study on a retrospective data collection, similar to previous IS studies [e.g., 40], whereas a longitudinal study might have provided more data.

We also set a foundation on which future research can build. Researchers might further study synergies between non-digital and digital BMs and eventually derive (based on single case studies or econometric analyses), the economic impact of such synergies. Also, additional types of interaction between established non-digital and digital BMs such as conflicts might be of interest for researchers (e.g., competition between BMs on organizational level or overload of co-workers who have to comprehend different BMs on an individual level).

\section{Conclusion}

Digital BMs are increasingly prevalent in the global economy, not only through start-ups but also through established companies undergoing a digital 
transformation. Yet, previous research has mostly studied BMs in isolation, neglecting possible synergies with the established non-digital BM. Using the business model canvas and the theories of resource relatedness and complementarity we extend existing research and uncover multiple synergy possibilities from which not only the additional digital BM but also the established non-digital BM benefits. While synergies notably regarding shared channels and customer relationship allow the digital BM to jump-start its growth, the established BM profits from an increasing value proposition with little additional effort. We also derive major guidelines for practitioners. These guidelines equip managers with initiatives to actually get in the required stance to identify and unlock synergies afterwards.

\section{References}

[1] I. M. Sebastian, M. Mocker, J. W. Ross, K. G. Moloney, C. Beath, and N. O. Fonstad, "How Big Old Companies Navigate Digital Transformation," MIS Quarterly Executive, vol. 16, no. 3, 2017.

[2] T. Hess, C. Matt, A. Benlian, and F. Wiesböck, "Options for Formulating a Digital Transformation Strategy," MIS Quarterly Executive, vol. 15, no. 2, 2016.

[3] Daimler AG. (2018, 05.06.2019). A new record: 22.9 million customers worldwide trust in mobility services from Daimler $A G \quad$ [Press release]. Available: https://bit.ly/2MuWCii

[4] G. Remane, A. Hanelt, F. Wiesböck, and L. M. Kolbe, "Digital Maturity in Traditional Industries - An Exploratory Analysis," presented at the European Conference on Information Systems, Portugal, 2017.

[5] B. W. Wirtz, A. Pistoia, S. Ullrich, and V. Göttel, "Business Models: Origin, Development and Future Research Perspectives," Long Range Planning, vol. 49, no. 1, pp. 36-54, 2016.

[6] W. K. Smith, A. Binns, and M. L. Tushman, "Complex Business Models: Managing Strategic Paradoxes Simultaneously," Long Range Planning, vol. 43, no. 2-3, pp. $448-461,2010$.

[7] A. Osterwalder and Y. Pigneur, "Designing Business Models and Similar Strategic Objects: The Contribution of IS," Journal of the Association for Information Systems, vol. 14, no. Special Issue, pp. 237-244, 2013.

[8] P. Peters, The Cambridge Dictionary of English Grammar. Cambridge: Cambridge University Press, 2013, p. 400.
[9] C. W. L. Hill and R. E. Hoskisson, "Strategy and Structure in the Multiproduct Firm," The Academy of Management Review, vol. 12, no. 2, pp. 331-341, 1987.

[10] A. Osterwalder and Y. Pigneur, T. Clark, Ed. Business model generation. Patrick van der Pij, 2010, p. 51.

[11] P. Milgrom and J. Roberts, "Complementarities and fit Strategy, structure, and organizational change in manufacturing," Journal of Accounting and Economics, vol. 19, pp. 179 -208, 1995.

[12] H. s. Tanriverdi and N. Venkatraman, "Knowledge relatedness and the performance of multibusiness firms," Strategic Management Journal, vol. 26, no. 2, pp. 97-119, 2005.

[13] J. Robins and M. F. Wiersema, "A Resource-Based Approach to the Multibusiness Firm: Empirical Analysis of Portfolio Interrelationships and Corporate Financial Performance," Strategic Management Journal, vol. 16, no. 4, pp. 277-299, 1995.

[14] D. Veit et al., "Business Models," Business \& Information Systems Engineering, vol. 6, no. 1, pp. 45-53, 2014.

[15] C. Legner et al., "Digitalization: Opportunity and Challenge for the Business and Information Systems Engineering Community," Business \& Information Systems Engineering, vol. 59, no. 4, pp. 301-308, 2017.

[16] G. Vial, "Understanding digital transformation: A review and a research agenda," The Journal of Strategic Information Systems, vol. published online, 2019.

[17] M. E. Porter and J. E. Heppelmann, "How Smart, Connected Products Are Transforming Companies," in Harvard Business Review vol. 2018, ed, 2015.

[18] C. Fuchs, P. Barthel, I. Herberg, M. Berger, and T. Hess, "Characterizing Approaches to Digital Transformation: Development of a Taxonomy of Digital Units," presented at the 14th International Conference on Wirtschaftsinformatik, Germany, 2019.

[19] C. Markides and C. D. Charitou, "Competing with Dual Business Models: A Contingency Approach," The Academy of Management Executive, vol. 18, no. 3, pp. 2236, 2004.

[20] C. Zott, R. Amit, and L. Massa, "The Business Model: Recent Developments and Future Research," Journal of Management, vol. 37, no. 4, pp. 1019-1042, 2011.

[21] G. Remane, A. Hanelt, B. Hildebrandt, and L. M. Kolbe, "Discovering new digital business model types: a study of technology start-ups from the mobility sector," presented at the 20th Pacific Asia Conference on Information Systems, Taiwan, 2016. 
[22] D. M. Steininger, J. Hoelz, and D. Veit, "Comparing Traditional and Electronic Business Models of the Music Industry: A Content Analytical Approach," presented at the Proceedings of the ConLife Academic Conference, 2012.

[23] M. E. Porter, Competitive Strategy. New York: The Free Press, 1980.

[24] M. Wiener, N. Hoßbach, and C. Saunders, "Omnichannel businesses in the publishing and retailing industries: Synergies and tensions between coexisting online and offline business models," Decision Support Systems, vol. 109, pp. 15-26, 2018.

[25] N. Hoßbach, "Dual Business Models: Going beyond Spatial Separation," presented at the Twenty-first American Conference on Information Systems (AMCIS), Puerto Rico, 2015.

[26] J. Toutaoui, "When 1+1 is Greater than 2: Concurrence of Additional Digital and Established Business Models within Companies," presented at the 14th International Conference on Wirtschaftsinformatik, Siegen, Germany, 2019.

[27] H. Tanriverdi, "Performance Effects of Information Technology Synergies in Multibusiness Firms," MIS Quarterly, vol. 30, no. 1, pp. 57-77, 2006.

[28] S. Radszuwill and G. Fridgen, "Forging a DoubleEdged Sword: Resource Synergies and Dependencies in Complex IT Project Portfolios," presented at the Thirty Eighth International Conference on Information Systems (ICIS), South Korea, 2017.

[29] R. K. Yin, Case Study Research: Design and Methods (Applied Social Research Methods). Thousand Oaks: Sage Publications, 2003.

[30] H. Klein and M. D. Myers, "A Set of Principles for Conducting and Evaluating Interpretive Field Studies in Information Systems," MIS Quarterly, vol. 23, no. 1, pp. 67-94, 1999.

[31] A. Benlian and T. Hess, "Opportunities and risks of software-as-a-service: Findings from a survey of IT executives," Decision Support Systems, vol. 52, no. 1, pp. 232-246, 2011.

[32] M. Keutel, B. Michalik, and J. Richter, "Towards mindful case study research in IS: a critical analysis of the past ten years," European Journal of Information Systems, vol. 23, no. 3, pp. 256-272, 2017.

[33] A. Benlian and I. Haffke, "Does mutuality matter? Examining the bilateral nature and effects of CEO-CIO mutual understanding," The Journal of Strategic Information Systems, vol. 25, no. 2, pp. 104-126, 2016.

[34] V. Beattie, S. Fearnley, and R. Brandt, "A Grounded Theory Model of Auditor-Client Negotiations,"
International Journal of Auditing, vol. 8, no. 1, pp. 1-19, 2004.

[35] K. M. Eisenhardt, "Building theories from case study research," Academy of Management Review, vol. 14, no. 4, pp. 532-550, 1989.

[36] M. B. Miles and A. M. Huberman, Qualitative Data Analysis: An Expanded Sourcebook. Thousand Oaks, California: Sage Publications, 1994.

[37] M. Schreieck, M. Wiesche, and H. Krcmar, "Design and Governance of Platform Ecosystems - Key Concepts and Issues for Future Research," presented at the TwentyFourth European Conference on Information Systems (ECIS), İstanbul, Turkey, 2016.

[38] A. Benlian, W. J. Kettinger, A. Sunyaev, and T. J. Winkler, "Special Section: The Transformative Value of Cloud Computing: A Decoupling, Platformization, and Recombination Theoretical Framework," Journal of Management Information Systems, vol. 35, no. 3, pp. 719739, 2018/07/03 2018.

[39] A. Tiwana, Platform Ecosystems Aligning Architecture, Governance, and Strategy. Waltham, MA: Elsevier, 2014, p. 280.

[40] E. W. T. Ngai, D. C. K. Chau, and T. L. A. Chan, "Information technology, operational, and management competencies for supply chain agility: Findings from case studies," The Journal of Strategic Information Systems, vol. 20, no. 3, pp. 232-249, 2011. 